\title{
A Mixed Methods Exploration of Economic Factors Role in Fashion Specialty Retailers' International Expansion and Performance
}

\author{
Danielle Sponder Testa \\ Arizona State University \\ Kelcie Slaton \\ Iowa State University \\ Elena Karpova \\ University of North Carolina at Greensboro
}

As globalization swells and businesses find success through expansion into new markets, there continue to be complexities to the factors that motivate retail international expansion. This study considers the modern relevance of economic factors in international expansion, specifically in fashion specialty retail, a continually expanding sector. The purpose of this study was to (1) examine what economic factors offoreign countries motivate fashion specialty retailers to open stores, and (2) analyze how those factors interacted with the brand's sales performance. Financial and economic data was retrieved and quantitively analyzed. Further, case-study analysis of each retailer provided context to the findings.

Keywords: international expansion, economic factors, fashion, specialty retail

\section{INTRODUCTION}

As globalization swells and businesses find success in new markets, various factors contribute to international retail expansion (Diallo, 2012; Pederzoli, 2006; Simpson \& Thorpe, 1995; Yoder, Visich, \& Rustambekov, 2016). Some researchers consider economic factors to be foundational motivations for international expansion due to the direct financial implications (Testa \& Lee, 2019). In extant international expansion research, it has been found that country's economic factors can lead to cutting costs, increasing margins, and/or maximizing resources and are a fundamental driver of internationalization decisions across an array of retail types (e.g., Williams, 1992). Other motivations for expansion, including competition and psychological motivations (Testa \& Lee, 2019), do not have similarly direct and measurable financial implications. However, extant literature has not explored motivations for international expansion as they relate to economic factors in fashion retail. An opportunity exists to evaluate the role of economic factors in fashion as the retail sector grows globally (Townsend, Surane, Orr, \& Cannon, 2017). The purpose of this study was to explore the significance of economic motivations of fashion specialty retailers, fashion retailers targeting specific consumer groups or product categories (Scarpi, 2006).

Past researchers have suggested that fashion retailers, which sell apparel, accessories and footwear (The 
NPD Group, 2018), may be the most essential sector to study in internationalization (Moore \& Burt, 2007). In the foundational review of internationalization, Hollander's (1970) recognized fashion retailers as abundant and successful in international expansion. Further, Doherty (2000) noted that international fashion retailer presence in Europe far outweighed the presence of international retailers from other industry sectors. Fashion retailers (reported as fashion specialty retailers) represent $8.4 \%$ of the top 250 global retailers (Deloitte and Stores Magazine, 2017). Further, in 2018, 29\% of announced new store openings in the U.S. were expected to be fashion retailers (Townsend, Surane, Orr, \& Cannon, 2017). Yet a recent review of the overarching role of economic factors in internationalization decisions has not been conducted (D'Andrea \& Arnold, 2003; Hutchinson et al., 2007). Therefore, an opportunity exists for an evaluation of factors impacting international expansion in the fashion retail sector today, specifically, if national economic factors can explain international expansion of large global fashion specialty retailers.

Extant research has explored the impacts of economic factors on retail success in international expansion, however, studies have focused on supermarkets such as Marks and Spencer (Burt et al., 2002; Yoder, Visich, \& Rustambekov, 2016) and mass merchants such as Walmart and Carrefour (Aoyama, 2007). Few studies have looked at the impact of economic factors on international expansion for fashion retail brands (D’Andrea \& Arnold, 2003; Lopez \& Fan, 2009; Wigley \& Moore, 2007) or fashion specialty retailers, who rely heavily on brand identity and consumer relationships to determine new market strategies (Scarpi, 2006). The focus of this study was fashion retailers due to the sector's major contribution to the global retailing system (Olanubi, 2017), continued growth internationally, and specifically the fashion specialty sub-sector due to the consumer catering and relationships (Scarpi, 2006).

\section{Theoretical Foundation}

This study is framed by Testa and Lee's (2019) conceptual model addressing hierarchical motivations and predictors of success in international expansion. Testa and Lee (2019) proposed that motivations for retail internationalization (i.e. international expansion) are hierarchical, each leading to increased likelihood for success in terms of profitability and brand equity. The hierarchical levels begin with economic factors as a foundation, then proceed to competitive factors, and psychological motivations. Within Testa and Lee's (2019) model, it is not necessary for brands to address all motivational factors, although it is posited that success will be greater when economic, competitive, and psychological factors are all addressed. This study explored the first level of the model, economic factors, applied in the context of fashion retail sector.

Foundational research in general retailing has shown organizations leaning heavily on economic factors in international expansion (Williams, 1992), however, more recent research has placed greater emphasis on competitive and psychological factors which are considered higher-order motivations in Testa and Lee's framework (2019). The importance of each hierarchical level has not been evaluated specifically in fashion retail. Therefore, this study examines the relationship between the foundation layer, economic motivations, and business performance (see figure 1). 
FIGURE 1

\section{ADAPTED TESTA AND LEE (2019) THEORETICAL FRAMEWORK}

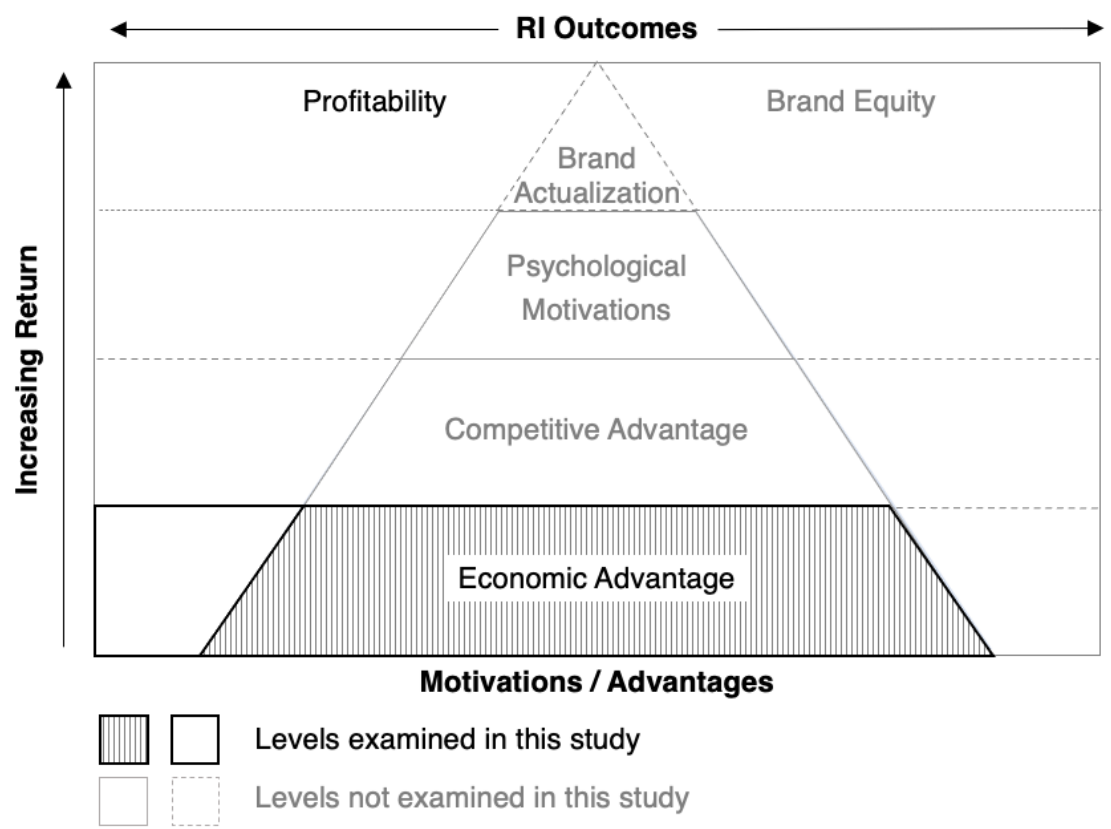

\section{Purpose}

The purpose of this study was to (1) examine what economic factors in foreign countries can explain fashion retailers' international expansion, and (2) analyze success of fashion retailers in international versus domestic markets. The study provides a statistical analysis of how host market economic factors relate to new store openings, as well as insight as to how these economic factors can explain fashion retailers' international expansion decisions and how international performance compares to domestic performance for the largest global fashion retailers. This work contributes to existing research on international expansion and the role of national economic factors.

\section{LITERATURE REVIEW}

\section{Fashion Retail}

Researchers have investigated international growth and success of individual fashion retailers, and cross-sector studies which include fashion among others have also been conducted. D'Andrea and Arnold (2003) examined Zara's model of expansion. Lopez and Fan (2009) studied Zara, examining the retailer's process towards international growth. The authors found three distinctions from the traditional "stage" model of expansion: supply chain, franchise and joint ventures, and method of creating brand awareness. Chan, Finnegan, and Sternquist (2011) conducted a study of 200 largest international retailers, focusing on grocery, discount, and cross-category retailers, with fashion retailers included. The authors found that economic factors, such as gross national income and level of development, contributed to firms' success in international markets. No recent studies have analyzed the fashion retail sector specifically in relation to international expansion.

\section{International Expansion}

At the end of the $20^{\text {th }}$ century, international retail growth was accelerating due to globalization and continues to expand in the $21^{\text {st }}$ century (Surugiu \& Surugiu, 2015). ). In coming years, NSOs in foreign markets are expected to outnumber store openings in domestic markets (Deloitte Touche Tohmatsu Limited, 2019). International expansion, in this article, will be used to refer to the opening of new stores in 
a non-domestic market. In international expansion, companies are faced with the decision of selecting locations for new store openings (NSOs). Wigley and Moore (2007) used NSOs as a predictor of international retail expansion success. Similarly, Chan, Finnegan and Sternquist (2011) used store openings as a measure of retail growth and, combined with net sales, found it to be an indicator of expansion success. This study focuses on store count, specifically new store openings and closures, to track expansion. In this study, NSOs will be used to refer to net new store openings and closures in existing markets as well as in entirely new markets.

\section{Economic Factors in International Expansion}

Economic factors refer to characteristics of a country, region, or society in which businesses operate (Hill \& Hult, 2019). Economic attractiveness of host markets is a major factor in making international expansion decisions (Alexander \& Doherty, 2009). A country's economic factors reflect the retail market opportunities and can attract retailers looking for growth through financial and economic opportunity (Quinn, 1999). Karande and Lombard (2005) found that population density and per capita income impacted the location decision of home repair and office supply specialty retailers. According to Chan, Finnegan, and Sternquist (2011), economic characteristics of a host country should be considered when a retailer begins to outline their plan to expand internationally. The authors found that population size, gross national income, and level of development contributed to firms' success in international markets in a study of 200 large retailers from various industry sectors. Based on extant research, three economic factors were considered as major determinants for fashion retailers to choose countries to enter: level of development, population size, and gross national income.

\section{Level of Development}

Country's level of development determines the economic, political and social systems that create wellbeing on a sustainable, long-term basis (Barder, 2012). Several indices exist to measure levels of development, including the Human Development Index (HDI) created by the United Nations (United Nations, n.d.) and the Trade and Development Index (TDI) (United Nations, 2005). HDI considers factors of life expectancy from birth, education, and standard of living (GNI per capita) to establish each country's level of development. TDI focuses on trade and economic factors such as structural and institutional development and trade policies.

Alexander and Doherty (2009) emphasized that retailers in developed nations favor expansion to similarly developed nations. Further, Chan et al. (2011) examined the relationship between countries' level of development and retailer's performance after expanding to these international markets. The authors found a positive relationship between level of development and retailer's performance measured by ROI and sales compounded with annual growth rate. Based on the previous research, level of country development is an important predictor of international retail expansion. However, no studies in the fashion retailing sector have examined the relationship between level of country development and expansion to foreign markets. Therefore, it was posited that:

H1. Level of development of a country is positively related to whether fashion specialty retailers open new stores in that country.

\section{Population}

Population refers to the number of people inhabiting a country or region (Hill \& Hult, 2019). Alexander and Doherty (2009) argued that population is a crucial factor in host markets selection. For example, countries with high population have a greater demand for personal care items (Luo, 2000). In a study of foreign investment of 328 companies in newly industrialized countries, Makino, Lau, and Yeh (2002) determined that countries with large population enticed retailers to consider international expansion. It was

found that countries with large population possessed a greater demand even if these countries do not have very high incomes. Therefore, it was posited that: 
H2. Population of a country is positively related to whether fashion specialty retailers open new stores in that country.

\section{Gross National Income}

Gross national income (GNI) is an economic factor referring to the combination of gross domestic product and income received from abroad (Organisation for Economic Co-operation and Development, 2018). Chan et al. (2011) reported a positive relationship between gross national income of a country and retailer's performance in foreign markets measured through net sales and return on investment. Additionally, according to Karande and Lombard (2005), retailers expand to countries with higher income, as an indicator that consumers have the monetary means to purchase the goods the retailers are offering in that market. Based on previous research, gross national income has been found to be a significant factor when selecting countries for international expansion. Therefore, it was posited that:

H3. GNI of a country is positively related to whether fashion specialty retailers open new stores in that country.

\section{Performance Indicators}

As retailers expand to new markets, net sales may be used as an indicator of success (Assaf et al., 2012; Wigley \& Moore, 2007). Net sales are total sales minus allowances, discounts, and returns (Bragg, 2017). During the period of 2000 to 2011, the world's top ten retailers experienced a $400 \%$ increase in net sales from their international stores (Corstjens \& Lal, 2012). Tatoglu, Demirbag, and Kaplan (2003) concluded that increased sales was the number one motivation of Western European fashion and food retailers to expand to Central and Eastern Europe. A Mintel report (2003) analyzing the failed internationalization of Marks and Spencers and demonstrated the significance of sales in successful international growth. Further, Wigley and Moore (2007) found that sales were a direct indicator of a firm's success in a review of Europe's top 18 specialty clothing (i.e. fashion) retailers. In this study, net sales will be evaluated to address success through financial performance.

\section{H4. International NSOs are}

(a) positively related to a retailer's increase in net sales

(b) are more significantly related to a retailer's increase in net sales than domestic NSOs.

\section{METHOD}

A mixed methods approach was utilized for data collection and analysis. Initially, retailer's storeexpansion and financial data was quantitatively evaluated over a 4-year period to demonstrate change over time. This data was combined with quantitative analysis of country-level economic data of the countries that the selected retailers had a presence in to showcase the impact of various economic factors. Following quantitative analysis, qualitative analysis of public reporting of each brand was conducted to contextualize the motivations for international expansion and subsequent performance outcomes. The utilization of a mixed methods approach provided rich data demonstrating both how and why retailers may have expanded, and performed better/worse, in specific markets.

\section{Retailer Selection}

The largest global fashion specialty retailers were considered for this research. To be included in the study, retailers needed to (1) have an international store presence, (2) be a public company with financial data available for analysis, and (3) had to have store data by country available. To identify the largest fashion specialty retailers, several industry reports, such as the National Retail Federation's annual 'Global 250 chart' (Deloitte and Stores Magazine, 2017), as well as annual financial statements of companies were examined (e.g., Abercrombie \& Fitch, 2017; Fast Retailing, 2016; H\&M, 2017; Inditex, 2017; L Brands, 2017). Inditex, H\&M, Fast Retailing, L Brands, Abercrombie \& Fitch (A\&F), and Gap Inc. were identified 
to represent the top five largest fashion retailers in the world, excluding off-price retailers (Fast Retailing 2016; Deloitte and Stores Magazine, 2017). These five companies were examined based on the three outlined criteria. Brands that met the criteria were included in the study, and those that did not were removed.

Limitations were presented with Gap Inc.'s annual financial reports which did not include data for new stores openings or net sales by individual country. Therefore, the company was excluded from the study. Further, information limitations regarding Fast Retailing's international stores and net sales by country reduced the scope of Fast Retailing's stores to only include the UNIQLO brand. However, UNIQLO represents the majority (84\%) of Fast Retailing sales (Fast Retailing, 2012). Therefore, the five companies analyzed in this study were Inditex, H\&M, UNIQLO, L Brands, and A\&F (see Table 1).

\section{TABLE 1 \\ FASHION SPECIALTY RETAILER RANKINGS, DOMESTIC MARKETS, AND INTERNATIONAL EXPANSION BY REGION}

\begin{tabular}{|c|c|c|c|}
\hline Rank & Retailer & Domestic Market & International Expansion \\
\hline 43 & Inditex & Europe (Spain) & $\begin{array}{l}\text { Africa, Asia, Australia/New Zealand, Europe, } \\
\text { Middle East, North America, South America, } \\
\text { Southeast Asia, Russia, }\end{array}$ \\
\hline 47 & $\mathrm{H} \& \mathrm{M}$ & Europe (Sweden) & $\begin{array}{l}\text { Africa, Asia, Australia/New Zealand, Europe, } \\
\text { Middle East, North America, South America, } \\
\text { Southeast Asia, Russia, }\end{array}$ \\
\hline 67 & UNIQLO & Asia (Japan) & $\begin{array}{l}\text { Asia, Australia/New Zealand, Europe, North } \\
\text { America Southeast Asia, Russia, }\end{array}$ \\
\hline 78 & L Brands & North America (U.S.) & Asia, Europe \\
\hline 248 & $A \& F$ & North America (U.S.) & Asia, Europe, Middle East \\
\hline
\end{tabular}

Notes. Ranking is within all global retailing. Regions categorized by Internet World Stats.

Sources: Abercrombie \& Fitch Annual Report 2012 \& 2016; Deloitte and Stores Magazine, 2017; Fast Retailing Annual Report 2012 \& 2016; H\&M Annual Report 2013 \& 2017; Inditex Annual Report 2012 \& 2016; L Brands Proxy Statement 2013\& 2017 Annual Meeting of Stockholders and 2012 \& 2016 Annual Reports.

\section{Data Collection}

To compare the five fashion retailers' performance, two years were selected: 2012 and 2016. This timeframe was selected based on two factors: (1) the early 2010s was a period of significant international retail growth, (A.T. Kearney, 2016) and (2) based on review of available information, sufficient information was available for all retails for the years of 2012 and 2016 regarding international markets by country.

\section{Retailers' Data}

New stores opening (NSO) data as well as net sales for Inditex, H\&M, UNIQLO, L Brands, and A\&F were gathered from the respective annual financial reports. Year-end annual reports for 2012 and 2016 were reviewed for each of the five fashion retailers to gather information including number of stores (including NSOs) by country and net sales by domestic market, international market, and total company. Available net sales numbers included only aggregate data: for domestic/home market and for overall international market combined, therefore, it was not possible to analyze net sales performance by individual country. However, new store openings data were available for all countries where the five retailers had presence in both years, 2012 and 2016. Company performance was measured through: (1) net sales and (2) percent change in net sales during the 2012-2016 timeframe. Net sales showed overall performance, whereas percent change allowed comparison of improvement of sales across retailers at different financial levels. 


\section{Country's Development Indicators}

To examine which economic factors (i.e., country's level of development, population size, and gross national income) serve as determinants for selection of countries for international expansion, the data were collected for 62 individual countries. The countries include all markets with NSOs for the selected retailers during the specified timeframe. The countries' economic data were collected for the year of 2012. Data from 2012 were used to examine factors of international markets at the beginning of the expansion period.

In order to measure the level of development of the host country, Human Development Index (HDI) was used (Human Development Index, n.d.). HDI is a composite index calculated based on the following factors: (1) life expectancy at birth; (2) education; and (3) standard of living. United Nations Development Program was used to collect the HDI scores for all 62 countries (United Nations, n.d.). The World Bank (2018) database was used to gather information on population and gross national income (GNI).

\section{Data Analysis}

To test the research hypotheses, the total number of new stores opened during the four-year period, from 2012 to 2016, by the five fashion retailers Inditex, H\&M, UNIQLO, L Brands, and A\&F was used as the dependent variable $(\mathrm{X})$. The independent variables tested were the HDI scores (HDI), population size (Population), and gross national income (GNI). The study employed a multiple regression model using least square approximation (Ott and Longnecker, 2010) (Equation 1).

$\mathrm{X}=\mathrm{b}_{0}+\mathrm{b}_{1} \mathrm{HDI}+\mathrm{b}_{2}$ Population $+\mathrm{b}_{3} \mathrm{GNI}+\mathrm{e}$

\section{Retailer Validation}

Each retailer included in the analysis took unique steps towards international expansion and publicly reported various motivations and reasons for expanding. Therefore, following initial data analysis, an indepth analysis of each brand's performance and public reports was conducted to contextualize international expansion, continued presence in non-domestic markets, and evaluate external factors that may further affect the research findings.

\section{RESULTS}

\section{Preliminary Analysis}

To examine the relationship between economic factors and NSOs in foreign markets, a correlation matrix for the independent variables was conducted to check for multicollinearity (see Table 2). Each independent variable's correlation coefficient was .5 or lower, which is below the typical cutoff of .8 (Berry \& Feldman, 1985).

TABLE 2

CORRELATION MATRIX FOR INDEPENDENT VARIABLES

\begin{tabular}{lllll}
\hline & HDI & Population & GNI & Consumption \\
\hline HDI & 1.000 & & & \\
Population & -0.24 & 1.000 & & \\
GNI & 0.18 & 0.50 & 1.000 & \\
\hline
\end{tabular}

\section{Hypotheses Tests}

The regression model was found to be statistically significant, $F(3,84)=38.27, p<.0001$ (see Table $3)$. The parameter estimators of population $\left(\mathrm{b}_{2}=2.97, p<.0001\right)$ and GNI $\left(\mathrm{b}_{3}=1.65, p=.009\right)$ were statistically significant, supporting Hypotheses 2 and 3, respectively. HDI $\left(b_{1}=105.57, p<.2789\right)$ was not statistically significant, therefore Hypothesis 1 was rejected. 
TABLE 3

RESULTS OF MULTIPLE REGRESSION WITH HDI, POPULATION, AND GNI

\begin{tabular}{lllll}
\hline & $\beta$ & Standard Error & t Statistics & $p$ \\
\hline Intercept & -76.39 & 77.95 & -0.98 & 0.3298 \\
HDI & 105.57 & 96.86 & 1.09 & 0.2789 \\
Population & 2.97 & 4.83 & 6.14 & $<.0001$ \\
GNI & 1.65 & 4.40 & 3.76 & .0003 \\
\hline
\end{tabular}

Note. Adjusted $\mathrm{R}^{2}=.56(p<.0001)$

After $\mathrm{H} 1$ was found not to be a statistically significant, the multiple regression model was refit with the dependent variable of the total new stores opened between 2012 and 2016 and the independent variables of population size and GNI (Equation 2). The regression model was statistically significant, $F(2,88)=58.76$, $p<.0001$ (see Table 4). Of the total variance, 56\% was explained by the two independent variables (adjusted $\left.\mathrm{R}^{2}=56 \%\right)$. The parameter estimators of population size $\left(\mathrm{b}_{1}=2.75, p<.0001\right)$ and $\mathrm{GNI}\left(\mathrm{b}_{2}=1.84, p<.0001\right)$ were statistically significant. It was found that population size and gross national income of host countries are significantly and positively related to new store openings by five fashion retailers in foreign countries. Thus, a $1 \%$ increase in population resulted in a $2.75 \%$ increase in new store opening. Further, a $1 \%$ increase in GNI resulted in a $1.84 \%$ increase in new store opening.

$\mathrm{X}=\mathrm{b}_{0}+\mathrm{b}_{1} \mathrm{HDI}+\mathrm{b}_{2}$ Population $+\mathrm{b}_{3} \mathrm{GNI}+\mathrm{e}$.

TABLE 4

RESULTS OF MULTIPLE REGRESSION WITH POPULATION AND GNI

\begin{tabular}{lllll}
\hline & $\beta$ & Standard Error & t Statistics & $p$ \\
\hline Intercept & 7.35 & 7.95 & 0.92 & 0.3578 \\
Population & 2.75 & 4.34 & 6.33 & $<.0001$ \\
GNI & 1.84 & 4.03 & 4.56 & $<.0001$ \\
\hline
\end{tabular}

Note. Adjusted $\mathrm{R}^{2}=.56(\mathrm{p}$ value $<.0001)$

\section{Retailers Performance}

Between 2012 and 2016, four of the five companies experienced increases in net sales (see Figure 2): Inditex (29 billion USD, 46\% growth), H\&M (22 billion USD, 15\% growth), UNIQLO (13 billion USD, $79 \%$ growth), and L Brand (13 billion USD, 20\% growth). In contrast, A\&F experienced a decrease in net sales ( 2 billion USD, $-26 \%$ decline). The same four out of five retailers showed an increase in total number of stores, with A\&F's count of stores decreasing by $15 \%$ (see Table 5). 
FIGURE 2

TOTAL NET SALES BY RETAILER, 2012-2016

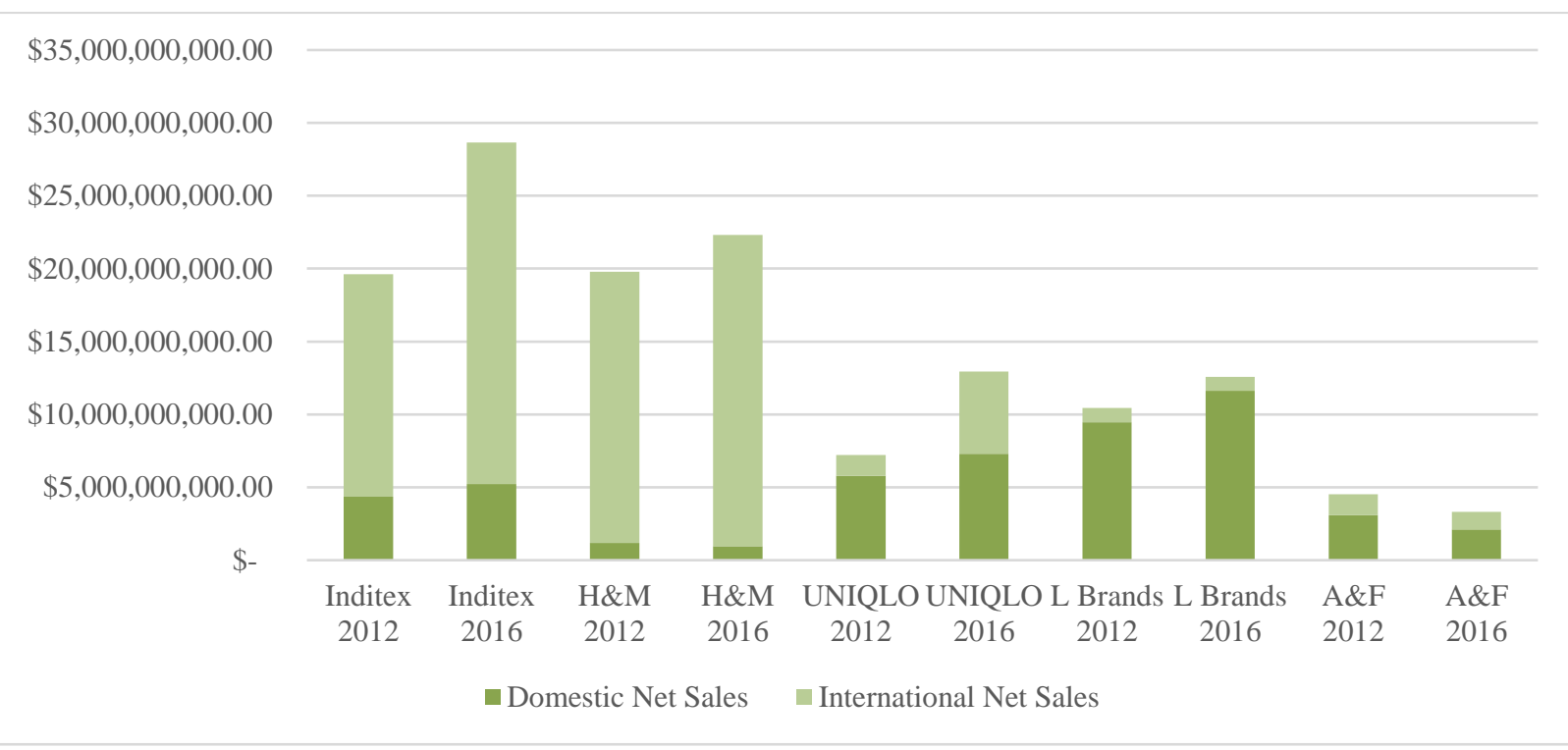

TABLE 5

PERCENT CHANGE IN NEW STORE OPENINGS AND NET SALES TABLE, 2012-2016

\begin{tabular}{lllllll}
\hline & Domestic & & International & Total & \\
\hline Brand & Stores & Net Sales & Stores & Net Sales & Stores & Net Sales \\
\hline Inditex & $-7 \%$ & $20 \%$ & $35 \%$ & $54 \%$ & $22 \%$ & $46 \%$ \\
H\&M & $-1 \%$ & $-17 \%$ & $61 \%$ & $15 \%$ & $57 \%$ & $15 \%$ \\
UNIQLO & $-1 \%$ & $26 \%$ & $243 \%$ & $294 \%$ & $60 \%$ & $79 \%$ \\
L Brands & $5 \%$ & $23 \%$ & $38 \%$ & $-4 \%$ & $8 \%$ & $20 \%$ \\
A\&F & $-22 \%$ & $-31 \%$ & $33 \%$ & $-16 \%$ & $-15 \%$ & $-26 \%$ \\
\hline
\end{tabular}

Three of the five companies experienced increases in international net sales: Inditex (23 billion USD, 54\% growth), H\&M (21 billion USD, 15\% growth), and UNIQLO (6 billion USD, 294\% growth). In contrast, two companies witnessed a decrease in net sales: A\&F (1 billion, -16\% decline) and L Brand (1 billion USD, $-4 \%$ decline). The three retailers whose performance was driven by international markets (Inditex, H\&M, UNIQLO) also had significant store growth in international markets. Inditex and H\&M saw the majority of their net sales from their international stores, whereas UNIQLO, L Brands and A\&F saw the majority of their net sales from their domestic stores.

\section{Comparison Based on Home Market}

There were differences in store growth based on the home market for the five retailers. Both U.S. retailers, $\mathrm{L}$ Brands and $\mathrm{A} \& \mathrm{~F}$, had by far greater domestic and lowest international presence by store counts: $90 \%$ and $80 \%$ of stores were domestic, respectively, in 2016. Further, L Brands was present in only three foreign countries, whereas $A \& F$ had a larger international presence (21 countries).

For the two European retailers, Inditex and H\&M, the trends were just the opposite of the U.S. retailers. Both had the highest international presence and lowest domestic presence by store counts, 58\% and 96\% international stores, respectively, in 2016. Both brands were present in many more countries than the U.S. retailers in both 2012 (83 and 46 countries, respectively) and 2016 (93 and 62 countries, respectively) (see Table 6). UNIQLO, the Japanese retailer, fell right in the middle of U.S. and European retailers with 47\% 
of stores located in Japan and 53\% located internationally in 2016. However, this was a significant increase in international stores from 2012 when only $25 \%$ of the brand's stores were international.

\section{TABLE 6 \\ NUMBER OF INTERNATIONAL COUNTRIES WHERE SPECIALTY RETAILERS OPENED STORES}

\begin{tabular}{llll}
\hline Brand & International Countries 2012 & International Countries 2016 & $\%$ Change \\
\hline Inditex & 83 & 93 & $12 \%$ \\
H\&M & 46 & 62 & $35 \%$ \\
UNIQLO & 7 & 14 & $100 \%$ \\
L Brands & 2 & 3 & $50 \%$ \\
A\&F & 16 & 18 & $13 \%$ \\
\hline
\end{tabular}

\section{Inditex}

Inditex and H\&M had similar net sales (approx. 20 billion USD total) in 2012, however, by 2016, Inditex became a clear leader with almost 29 billion USD net sales (see Figure 2). While Inditex showed an increase in net sales for the domestic stores (see Table 5), the company's growth was fueled by its international stores. The company had the highest number of stores in both $2012(3,708)$ and $2016(9,573)$ (see Figure 3). Notably, Inditex recorded $22 \%$ growth in the total number of stores that was fueled by international expansion (35\% increase in stores). In contrast, the number of domestic stores declined by $7 \%$.

Inditex, as the largest specialty fashion retailer by both store count and sales, found it's position as the leader through rapid international expansion (Dishman, 2012). While the retailer initially expanded to markets near their home market, internal capabilities allowed them to rapidly expand to countries near and far (Lopez and Fan, 2009). Due to Inditex's advanced supply chain, the company was able to produce and source from either hemisphere, allowing them to explore expansion opportunities in any country (Thompson, 2012). Further, due to collaborative design and catered assortments based on regional climate and trend, Inditex's largest brand Zara has been able to serve markets as far reaching as Australia, Taiwan, Azerbaijan, South Africa and Peru (Dishman, 2012; Thompson, 2012).

\section{FIGURE 3 \\ NUMBER OF STORES BY RETAILER FOR DOMESTIC AND INTERNATIONAL MARKETS, 2012 AND 2016}

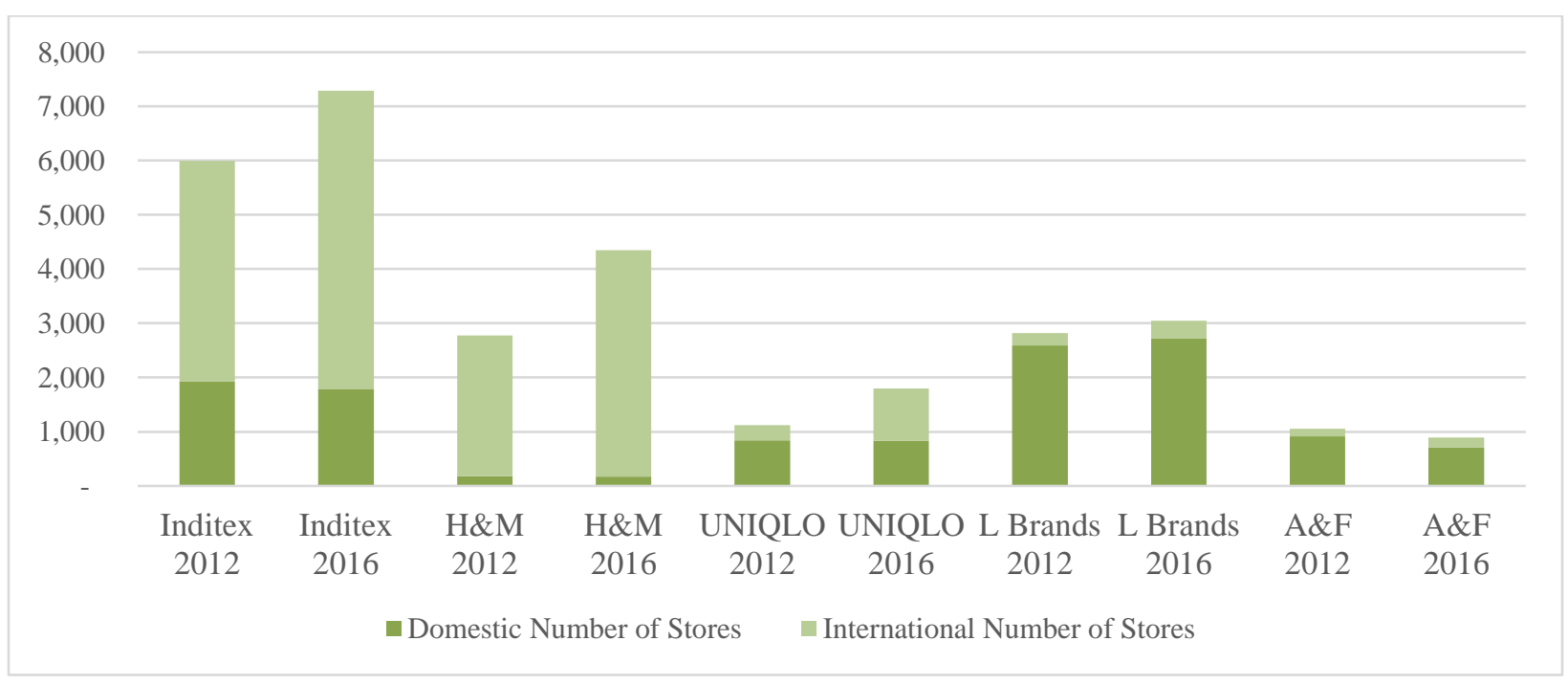




\section{$H \& M$}

The company had the second highest number of stores in both $2012(2,776)$ and $2016(4,315)$. The total store count increased from 2012 to 2016 (see Figure 3). In contrast to Inditex, H\&M showed a small decrease $(-17 \%)$ in net sales for their domestic stores, while brand growth was fueled by international stores (net sales: $+15 \%$ ) (see Table 5). H\&M had a 57\% growth in the total store count driven by international expansion.

H\&M pursued a similar expansion strategy as Inditex, expanding to both developed and developing nations (Ringstrom, 2012; Wells and Danskin, 2013). Historically, H\&M had been larger than Inditex but in the early 2000s Inditex took over as the largest global apparel retailer (Ringstrom, 2012). Industry insiders and journalists speculated that the market choices for H\&M between 2012 and 2016 were based on Inditex's selections (Ringstrom, 2012; Wells and Danskin, 2013). H\&M's focus on brand diversification, referring to the growth of their non-namesake labels such as COS, \& OtherStories, Cheap Monday, and Monki, would support a chase-strategy in which the brand trusted their key competitor, Inditex, to select the best markets to enter (Milne, 2012).

\section{UNIQLO}

UNIQLO's growth is particularly unique as domestic store count decreased by $1 \%$, whereas international stores grew by $246 \%$, leading to an overall increase in the number of stores (see Figure 3 ). As a result, the brand became a significant player in international fashion retailing by 2016. The brand increased the international store count from 279 in 2012 to 958 in 2016 while decreasing domestic stores only slightly from 845 in 2012 to 837 in 2016 . Even with the slight decrease to domestic store count, UNIQLO increased domestic sales by $26 \%$ over the four-year period, whereas international sales increased by $294 \%$, slightly outperforming the store count increase internationally $(246 \%)$ (see Table 5 ).

Fast Retailing, the parent company of UNIQLO, had the goal in 2012 to become the world's largest retailer by 2020 (Fast Retailing, 2012; Kenneally, 2014). However, the retailer took a different approach than competitors Inditex and H\&M; Fast Retailing wanted to operate like the tech companies of Silicon Valley. Fast Retailing did not set it sights on entry price points or developing markets, but rather techfocused product, consumers, and quality products worth a slightly elevated retail price (Tate, 2012). Therefore, UNIQLO set its sights on the USA, opening 45 stores in the market. However, while popular press addressed UNIQLO's expansion to the USA, Fast Retailings CEO Tadashi Yanai had set his sights on a more immediate target of becoming the largest retailer in Asia through rapid growth in China (Fast Retailing, 2012). This study found that while UNIQLO did expand to the USA, most of the brands growth came from a market closer to, China. With 327 new stores in China between 2012 and 2016, UNIQLO opened more than seven-times and many stores in China as the U.S.A.

\section{Brands}

L Brands had the largest domestic operations (i.e., store count and net sales) in 2012. In 2016 L Brands domestic operations had grown further, maintaining the largest domestic business. In contrast, by 2016 the brand's international store growth was slow and international net sales had decreased, representing the worst performance of the five companies internationally. Total store count for L Brands grew by $8 \%$ between 2012 and 2016. The growth was driven primarily by domestic stores, which increased from 2,590 to 2,726 stores (5\%) (see Table 5). In comparison, international stores grew $26 \%$ but represented a much smaller portion of the business: 231 international stores in 2012 and 319 in 2016. While the growth in domestic stores corresponded to a $23 \%$ increase in domestic sales, the growth in international stores corresponded to a $4 \%$ decline in sales.

Between 2012 and $2016 \mathrm{~L}$ Brands continued to go through changes as the brand focused on its Victoria's Secret, La Senza, and Bath \& Body Works brands. In 2010 Limited Brands sold its namesake brand, The Limited; two years later, in 2012 the retailer changed their name to L Brands (Eaton, 2013; L Brands, 2018). L Brand's executed a focused growth strategy with NSOs in only three international markets between 2012 and 2016: Canada, the UK, and China. 


\section{Abercrombie \& Fitch $(A \& F)$}

A\&F had the lowest number of stores in both 2012 (1,053 total; 912 domestic, 141 international) and 2016 (897 total; 709 domestic, 188 internationally). The retailer experienced a decrease in domestic stores $(-22 \%)$ which drove a total store decline $(-15 \%)$. A\&F also experienced a total sales decline $(-26 \%)$ driven by eroding sales in both domestic $(-31 \%)$ and international $(-16 \%)$ markets.

Between 2012 and 2016 Abercrombie \& Fitch was struggling in their domestic (U.S.) market due to negative publicity regarding race, sexualization, and high pricing. The retailer faced lawsuits regarding racism and sexual harassment (Minato, 2012). The company faced criticism for their high prices and the situation was worsened when cotton prices increased causing their already struggling domestic margin to lessen (Gonzalez-Rodriguez, 2015; Trefis Team, 2015).

Despite struggles and closures in the U.S., Abercrombie \& Fitch continued to grow internationally with positive brand recognition in the international arena and found international stores to be $85 \%$ more productive based on sales per square foot (Eaton, 2014; Trefis Team, 2015). Unfortunately, Abercrombie \& Fitch's expansion to European tourist markets between 2012 and 2016 resulted in self-cannibalization and decline in store productivity (Trefis Team, 2015). Abercrombie \& Fitch's discovered a new (developing) market of opportunity though: China (Abercrombie \& Fitch, 2012; 2016). In 2014 the store had only 11 stores in China, recognizing the market opportunity, another 16 were open by 2016 (Abercrombie \& Fitch, 2016; Trefis Team, 2015).

At an aggregate level, international expansion positively impacted net sales. Therefore, H4a ,which stated that international expansion would positively relate to a retailer's increase in net sales, was supported. The companies with the highest overall net sales, as well as the highest increase in net sales through the study period, had the highest international presence and had aggressive expansion strategies. However, the two brands with more emphasis on domestic growth saw underperformance in their international NSOs. Therefore, H4b, which stated that international expansion would increase net sales more significantly than domestic expansion, was not supported.

\section{DISCUSSION}

The results suggested that the size of the market measured by the number of consumers (H2: population size) was a significant predictor of NSOs for fashion retailers. Further, a large portion of the fastest-growing cities are outside of developed Europe and North America, primarily in China and India. These fast-growing cities have been key source of fashion sales, supporting the finding that population matters in international expansion. This is consistent with executive surveys completed by BoF Team and McKinsey \& Company (2018) which found that, "Rapidly growing cities in emerging markets are particularly important growth centers for the fashion industry" (para. 3). It may be noted that in this study, both companies with strong sales (i.e., Inditex and H\&M), and companies with weaker sales (i.e., A\&F) chose to expand to high population markets suggesting that population of the host country may not relate to success in international expansion.

The research findings support shifts to higher density markets as population was found to be a significant indicator of fashion retail NSOs, but not based upon level of development (H1: level of development). Specifically, the findings suggested that country's level of development is a non-significant predictor of fashion retailer's international expansion. Inditex, the largest retailer in this study with the best sales performance internationally and domestically, demonstrated this finding by expanding rapidly to both developed and developing countries. This finding was in contrast to previous general retailing research (e.g., Alexander \& Doherty, 2009; Chan et al., 2011). The non-significance of country development level may represent one of the shifts in modern retailing. This suggests the changing relevance of economic factors in fashion retail; the finding may align with consumer-oriented shifts driven by non-economic factors.

In line with past research, the size of a market in terms of income (H3: GNI) was found to be a significant predictor for fashion retailers' international expansion. According to Karande and Lombard (2005), large countries in terms of overall output are a logical choice in leveraging strategic positioning 
during country selection. In this study, retailers that expanding to countries with higher GNI had higher sales, suggesting that there may be a relationship between GNI and international expansion success. Therefore, host market GNI is an area to be monitored to identify future market opportunities. It is expected by the current researchers that even as economic factors such as level of development change in relevancy, financial indicators for consumer spending will remain static as important indicators.

An impactful finding of this study was that international store growth had a disproportionately large impact on net sales compared to domestic store growth. However, this held true to varying extents based upon how aggressively brands expanded internationally. For the brands with a heavy investment in international growth (i.e., Inditex, H\&M, UNIQLO), international sales far outperformed the number of new stores, however for brands with a smaller investment in international growth (i.e., L Brands, A\&F), the investment underperformed domestic sales change. This finding underlines the importance of expanding to the right countries with appropriate consumer bases and suggests the presence of additional, significant, non-economic variables.

\section{CONCLUSION}

The companies in the study represented European, U.S., and Japanese fashion retailers. Through comparing sales and store growth both internationally and domestically, this study found that Inditex (Europe) and UNIQLO (Japan) saw the highest sales increase over the four-year period coinciding with rapid store growth, primarily in international markets. These two retailers also expanded to high population markets, with significant GNI, irrespective of the host country's level of development. In contrast, the two retailers who focused on domestic stores and less store growth, L Brands and A\&F (U.S.) saw less sales growth or sales decline. This study found that international expansion was much more rampant for European and Asian retailers than U.S. retailers. This trend suggest that rate of international expansion may rely on the size of the domestic market.

The findings from this study contribute important insights into the shifting significance of economic factors in fashion specialty retailer's international expansion. While host market's population and gross national income are relevant in modern expansion, it was found that in contrast to previous general retailing research (e.g. Alexander and Doherty 2009, Chan et al. 2011), country's level of development is not a significant predictor fashion specialty retailers' international expansion. Therefore, the findings of this study partially support the relationship between economic factors and financial performance in fashion retail as proposed in the theoretical retail framework by Testa and Lee (2019). It may be explored in future studies if emergent factors have replaced waning economic drivers, such as psychological motivations including key employee relationships with a host market or brand-wide sentiment.

While brand strategies and public perception varied drastically across retailers, consistent focus on high population and high-income markets aligned with the study results. Even retailers with a stated focus on expansion to developed markets continued their expansion in developing countries. It is important that researchers continue to evaluate that factors that motivate international expansion in our current contexts, as retailers and countries develop and change.

\section{LIMITATIONS AND FURTHER RESEARCH}

This study examined five of the largest fashion specialty retailers over a five-year period. The companies represented European, US, and Japanese companies. Therefore, the results of the study might be generalized to the fashion specialty retail sector. However, the results might not be generalizable to other retail sectors because some results were different from previous research findings of cross-sectional retailers' expansion. The outcomes of this research regarding development, population, and income will benefit both academics and retailers by enlarging the understanding of the factors that impact international fashion specialty retail expansion. The study results may provide insight impacting expansion plans of fashion specialty retailers in the future.

Opportunities exist for further research regarding fashion sectors and factors influencing international 
expansion. In total, the economic factors examined in this study explained 56 percent of variance in international new store openings. Other factors that potentially can explain fashion retailers' international expansion may be competition or psychological motivations for expansion. Future research might explore the impact of these other factors on international expansion of fashion retailers and their relationship to one another to explore the model proposed by Testa and Lee (2019). The opportunity exists to explore the impact of economic factors on international expansion in other retail sectors such as off-price retail, luxury, or department stores.

\section{REFERENCES}

A.T. Kearney. (2016). The 2016 global retail development index: Global retail expansion at a crossroads. Retrieved from https://www.atkearney.com/documents/10192/8226719/Global+Retail+ Expansion+at+a+Crossroads\%E2\%80\%932016+GRDI.pdf/dc845ffc-fe28-4623-bdd4b36f3a443787

Abercrombie \& Fitch. (2012). Abercrombie \& Fitch Annual Report 2012. Retrieved from http://www.annualreports.com/HostedData/AnnualReportArchive/a/NYSE_ANF_2012.pdf

Abercrombie \& Fitch. (2016). Abercrombie \& Fitch Annual Report 2016. Retrieved from http://www.annualreports.com/HostedData/AnnualReports/PDF/NYSE_ANF_2016.pdf

Alexander, N., \& Doherty, A.M. (2009). International Retailing. Oxford, UK: Oxford University Press.

Amed, I., Berg, A., Kappelmark, S., Hedrick, S., Andersson, J., Drageset, M., \& Young R. (2017). The state of fashion 2018. The Business of Fashion and McKinsey \& Company. Retrieved from https://cdn.businessoffashion.com/reports/The_State_of_Fashion_2018_v2.pdf

Aoyama, Y. (2007). Oligopoly and the structural paradox of retail TNCs: An assessment of Carrefour and Wal-Mart in Japan. Journal of Economic Geography, 7(4), 471-90.

Assaf, A.G., Josiassen, A., Ratchford, B.T., \& Barros, C.P. (2012). Internationalization and performance of retail firms: A Bayesian dynamic model. Journal of Retailing, 88(2), 191-205. Doi:10.1016/j.jretai.2011.11.005

Barder, O. (2012). What is development. Center for Global Development. Retrieved from https://www.cgdev.org/blog/what-development

Berry, W.D., \& Feldman, S. (1985). Multiple Regression in Practice (Quantitative Applications in the Social Sciences). SAGE Publications; Thousand Oaks. CA.

BoF Team \& McKinsey \& Company. (2018). 10 trends that will define the fashion agenda in 2018. Retrieved from https://www.businessoffashion.com/articles/ intelligence/10-trends-that-willdefine-the-fashion-agenda-in-2018

Bragg, S. (2017). The difference between gross sales and net sales. Accounting Tools. Retrieved from https://www.accountingtools.com/articles/what-is-the-difference-between-gross-sales-and-netsales.html

Burt, S.L., Mellahi, K., Jackson, T.P., \& Sparks, L. (2002). Retail internationalization and retail failure: Issues from the case of Marks and Spencer. The International Review of Retail, Distribution and Consumer Research, 12(2), 191-219.

Chan, P., Finnegan, C., \& Sternquist, B. (2011). Country and firm level factors in international retail expansion. European Journal of Marketing, 45(6), 1005-1022. Retrieved from http://www.emeraldinsight.com/doi/10.1108/03090561111119985

Corstjens, M., \& Rajiv L. (2012, April). Retail doesn't cross borders: Here's why and what to do about it. Harvard Business Review. Retrieved from https://hbr.org/2012/04/retail-doesnt-cross-bordersheres-why-and-what-to-do-about-it

D’Andrea, G., \& Arnold, D. (2003, March). Zara. Harvard Business School Press, Case 503-050.

Deloitte and Stores Magazine. (2017). 2017 global 250 chart. National Retail Federation. Retrieved from https://nrf.com/2017-global-250-chart

Deloitte Touche Tohmatsu Limited. (2019). Global Powers of Retailing 2019. Retrieved from 
https://www2.deloitte.com/content/dam/Deloitte/global/Documents/Consumer-Business/consglobal-powers-retailing-2019.pdf

Diallo, M.F. (2012). Retailers' internationalization in emerging markets: A comparative study of a french and a local retailer's key success factors in Brazil. International Business Research, 5(10), 91-99.

Dishman, L. (2012). The strategic retail genius behind Zara. Forbes. Retrieved from https://www.forbes.com/sites/lydiadishman/2012/03/23/the-strategic-retail-genius-behindzara/\#7bc691ec69d8

Doherty, A.M. (2000). Factors influencing international retailers' market entry mode strategy. Journal of Marketing Management, 16, 223-45.

Eaton, D. (2013). Limited Brands now L Brands, for now. Columbus Business First. Retrieved from https://www.bizjournals.com/columbus/blog/2013/03/limited-brands-now-l-brands-for-now.html

Eaton, D. (2014). Abercrombie \& Fitch to close 60-70 U.S. stores in 2014, but open 16 abroad. Columbus Business First. Retrieved from https://www.bizjournals.com/columbus/blog/2014/03/ abercrombie-fitch-to-close-60-70.html

Fast Retailing. (2012). Fast Retailing Annual Report 2012. Retrieved from http://www.fastretailing.com/eng/ir/library/annual.html

Fast Retailing. (2016). Fast Retailing Annual Report 2016. Retrieved from http://www.fastretailing.com/eng/ir/library/annual.html

Gap Inc. (2016). Annual report (2016). Retrieved from http://www.gapinc.com/content/dam/gapincsite/ documents/GPS\%202015\%20Annual\%20Report.pdf

Gonzalez-Rodriguez, A. (2015, April). Abercrombie \& Fitch margins to shrink as cotton prices rise. Fashion United. Retrieved from https://fashionunited.uk/news/business/abercrombie-fitchmargins-to-shrink-as-cotton-prices-rise/2015040116020

H\&M. (2013). H\&M Annual Report. Retrieved from https://about.hm.com/en/investors/reports.html H\&M. (2017). H\&M Annual Report. Retrieved from https://about.hm.com/en/investors/reports.html

Hill, C.W.L., \& Hult, G.T.M. (2019). International Business: Competing in the Global Marketplace (12 ${ }^{\text {th }}$ ed.). New York, NY: McGraw Hill Education.

Hollander, S.C. (1970). Who are the multinational retailers? In Multinational Retailing (pp. 14-53). East Lansing, MI: Michigan State University Press.

Hutchinson, K., Alexander, N., Quinn, B., \& Doherty, A.M. (2007). Internationalization motives and facilitating factors: Qualitative evidence from smaller specialist retailers. Journal of International Marketing, 15(3), 96-122.

Inditex. (2012). Annual Report 2012. Retrieved from https://www.inditex.com/documents/10279/246369/ AnnualReport_2012.pdf/06f98dd6-cb78-491d-be79-ee1e5afb2229

Inditex. (2016). Inditex Annual Report 2016. Retrieved from https://www.inditex.com/documents/10279/ 319575/Inditex+Annual+Report+2016/6f8a6f55-ed5b-41f4-b043-6c104a305035

Karande, K., \& Lombard, J.R. (2005). Location strategies of broad-line retailers: An empirical investigation. Journal of Business Research, 58(5), 687.

Kenneally, I. (2014). Uniqlo's new U.S. strategy: Big growth, big sizes. Sourcing Journal. Retrieved from https://sourcingjournal.com/topics/business-news/uniqlos-new-u-s-strategy-big-growth-bigsizes-9085/

L Brands. (2017). L Brands Proxy Statement for the 2017 Annual Meeting of Stockholders and 2016 Annual Report. Retrieved from https://www.lb.com/media/resources/annual-report

L Brands. (2018). Heritage. Retrieved from https://www.lb.com/our-company/heritage

Limited Brands. (2013). Limited Brands Proxy Statement for the 2013 Annual Meeting of Stockholders and 2012 Annual Report. Retrieved from https://www.lb.com/media/resources/annual-report

Lopez, C., \& Fan, Y. (2009). Internationalisation of the Spanish fashion brand Zara. Journal of Fashion Marketing and Management, 13(2), 279-296.

Luo, Y. (2000), Dynamic capabilities in international expansion. Journal of World Business, 35(4), 355378.

Makino, S., Lau, C.M., \& Yeh, R.S. (2002). Asset-exploitation versus asset-seeking: Implications for 
location choice of foreign direct investment from newly industrialized economies. Journal of International Business Studies, 33(3), 403-421.

Milne, R. (2012). H\&M branches out with Monki strategy. Financial Times. Retrieved from https://www.ft.com/content/3d0692b8-14ab-11e2-aa93-00144feabdc0

Minato, C. (2012). How Abercrombie \& Fitch CEO Mike Jeffries is screwing up America's sexiest brand. Business Insider. Retrieved from http://www.businessinsider.com/the-abercrombie-and-fitchdisaster-timeline-how-abercrombie-and-fitch-ceo-mike-jeffries-screwed-up-americas-sexiestbrand-2012-6

Mintel. (2003). Clothing Retailing - UK. Mintel International Group Ltd., London, UK.

Moore, C.M., \& Burt, S. (2007). Developing a research agenda for the internationalization of fashion retailing. In T. Hines \& M. Bruce (Eds.), Fashion Marketing: Contemporary Issues (pp. 68-85). Routledge.

Olanubi, S. (2017). Top 5 largest fashion retailers in the world. Tharawat Magizine. Retrieved from https://www.tharawat-magazine.com/facts/top-5-largest-fashion-clothing-retailersworld/\#gs.Rv4qC=0

Organisation for Economic Co-operation and Development. (2018). Gross National Income. Retrieved from https://data.oecd.org/natincome/gross-national-income.htm

Ott, R.L., \& Longnecker, M. (2010). An Introduction to Statistical Methods and Data Analysis. Belmont, CA: Duxbury Press.

Pederzoli, D. (2006). Conception and test of a comprehensive model of international strategy for retail companies. The International Review of Retail, Distribution and Consumer Research, 16(4), 415431.

Quinn, B. (1999). The temporal context of UK retailers' motives for international expansion. The Services Industry Journal, 19(2), 101-116.

Ringstrom, A. (2012, June). Analysis: H\&M on quest for growth with new fashion chains. Reuters. Retrieved from https://www.reuters.com/article/us-hm-expansion/analysis-hm-on-quest-forgrowth-with-new-fashion-chains-idUSBRE8530E520120604

Scarpi, D. (2006). Fashion stores between fun and usefulness. Journal of Fashion Marketing and Management, 10(1), 7-24.

Simpson, E.M., \& Thorpe, D.I. (1995). A Conceptual Model of Strategic Considerations for International Retail Expansion. The Service Industries Journal, 15(4), 16-24.

Surugiu, M.R., \& Surugiu, C. (2015). International Trade, Globalization and Economic Interdependence Between European Countries: Implications for Businesses and Marketing Framework. Procedia Economics and Finance, 32, 131-13.

Tate, R. (2012, October). UNIQLO'S CEO on his long, 'crazy' fight for the future of retail. Wired. Retrieved from https://www.wired.com/2012/10/uniqlos-ceo-future-of-retail/

Tatoglu, E., Demirbag, M., \& Kaplan, G. (2003). Motives for retailer internationalization to central and eastern Europe. Emerging Markets Finance and Trade, 39(4), 40-57.

Testa, D.S., \& Lee, Y.A. (2019). Economic, competitive, and psychological motivations for retail internationalization: Theorizing a motivations hierarchy. Journal of Advancement in Economics, Finance and Accounting, 6(1), 27-44.

The NPD Group, Inc. (2018). Shift in footwear and accessories spending sends warning signal for retail fashion, reports NPD. NPD. Retrieved from https://www.npd.com/wps/portal/npd/us/ news/pressreleases/2017/shift-in-footwear-and-accessories-spending-sends-warning-signal-for-retailfashion-reports-npd/

The World Bank. (2018). GNI, Atlas method (current US\$). Retrieved from https://data.worldbank.org/indicator/NY.GNP.ATLS.CD

Thompson, D. (2012, November). Zara's big idea: What the world's top fashion retailer tells us about innovation. The Atlantic. Retrieved from https://www.theatlantic.com/business/archive/2012/ 11/zaras-big-idea-what-the-worlds-top-fashion-retailer-tells-us-about-innovation/265126/

Townsend, M., Surane, J., Orr, E., \& Cannon, C. (2017). America's 'Retail Apocalypse' is really just 
beginning. Bloomberg. Retrieved from https://www.bloomberg.com/graphics/ 2017-retail-debt/ Trefis Team. (2015, August). Why Abercrombie \& Fitch's international expansion makes sense despite Europe concerns. Forbes. Retrieved from https://www.forbes.com/sites/greatspeculations/2015/ 08/13/why-abercrombie-fitchs-international-expansion-makes-sense-despite-europe-concerns/ $\# 5 \mathrm{e} 3 \mathrm{ac} 4 \mathrm{a} 677 \mathrm{af}$

United Nations. (2005). Trade and Development Report, 2005. United Nations Conference on Trade and Development. Retrieved from https://unctad.org/en/docs/tdr2005_en.pdf

United Nations. (n.d.). Human Development Index (HDI). United Nations Development Programme. Retrieved from http://hdr.undp.org/en/content/human-development-index-hdi

Wells, J.R., \& Danskin, G. (2013, June). Hennes \& Mauritz, 2012. Harvard Business Review. Retrieved from https://hbr.org/product/hennes-mauritz-2012/713512-PDF-ENG

Wigley, S., \& Moore, C.M. (2007). The operationalisation of international fashion retailer success. Journal of Fashion Marketing and Management, 11(2), 281-296.

Williams, D.E. (1992). Retailer internationalization: An empirical inquiry. European Journal of Marketing, 26(8/9), 8-24.

Yoder, S., Visich, J.K., \& Rustambekov, E. (2016). Lessons Learned from International Expansion Failures and Successes. Business Horizons, 59(2), 233-243. 